\title{
Antimicrobial Activity and Microbial Transformation of Ethyl p-Methoxycinnamate Extracted from Kaempferia galanga
}

\author{
MUHAMMAD NOR OMAR ${ }^{1 *}$, NOR HAZWANI MOHD HASALI ${ }^{1}$, \\ HELMI YOUSIF ALFARRA ${ }^{1}$, MOHD AMBAR YARMO ${ }^{2}$ and AHMAD MUZAMMIL ZUBERDI ${ }^{1}$ \\ 1Department of Biotechnology, Kulliyyah of Science, International Islamic University Malaysia (IIUM), \\ Jalan Sultan Hj. Ahmad Shah, Bandar Indera Mahkota, 25200 Kuantan, Pahang, Malaysia \\ ${ }^{2} S$ chool of Chemical Sciences and Food Technology, Faculty of Science and Technology \\ Universiti Kebangsaan Malaysia, 43600 Bangi, Selangor Malaysia. \\ ${ }^{*}$ Corresponding author E-mail: mnoromar@iium.edu.my
}

http://dx.doi.org/10.13005/ojc/300315

(Received: July 28, 2014; Accepted: September 02, 2014)

\begin{abstract}
Ethyl $p$-methoxycinnamate (EPMC), a major constituent of the Kaempferia galanga rhizome, was transformed to ethyl $p$-hydroxycinnamate (EPHC) using Aspergillus niger. The EPHC metabolite was elucidated by NMR spectroscopic technique. Antimicrobial microbial study found that EPHC was active against all strains tested with a good minimum inhibitory concentration (MIC). It was active against both Staphylococcus aureus and Bacillus cereus at MIC $333 \mu \mathrm{g} / \mathrm{ml}$ while against Pseudomonas aeruginosa, Escherichia coli and Candida albicans at MIC $111 \mu \mathrm{g} / \mathrm{ml}$. It was also shown that EPHC exhibited more growth inhibition potential than EPMC. Besides that, EPHC has shown the minimum bactericidal concentration (MBC) toward $B$. cereus, $P$. aeruginosa and $E$. coli at the concentration of $1000 \mu \mathrm{g} / \mathrm{mL}$ while EPMC did not show killing potential toward the tested microorganisms.
\end{abstract}

Key words: Biotransformation, Kaempferia galanga Linn, Ethyl p-methoxycinnamate, Ethyl $p$-hydroxycinnamate, Aspergillus niger, Antimicrobial.

\section{INTRODUCTION}

The need for a new antibiotic against pathogenic microorganism has increased due to the current problems of resistance associated with them ${ }^{1}$. Plant based antimicrobial agents have enormous therapeutically potential as they can serve the purpose without any side effect, that often associated with synthetic agents.
Malaysian natural product plants have been studied extensively. These include medicinal plant species from Andrographis ${ }^{2,3,4,5}$, Musa $^{6}$, Plumeria ${ }^{7}$, Citrus $^{8.9}$, Cymbopogon $^{10}$, Artocarpus $^{11}$, Alpinia $^{12}$ and Centella $^{13}$. However, plant species of Zingiberaceae continue to attract much phytochemical interests due to their culinary uses, besides their biological and pharmaceutical activities. Kaempferia galanga Linn., belongs to the Zingiberaceae family, is one 
of the plants that mainly distributed in tropics and subtropics of Asia. Besides Malaysia, it can be found in Southern China, Indochina and India ${ }^{14}$. It has been known from ancient times that the essential oil of $K$. galanga plays an important role in native medicine as it possesses interesting biological activities such as antimicrobial ${ }^{15}$, antihypertensive ${ }^{16}$, anticancer ${ }^{17}$ and antiproliferative activity ${ }^{18}$.

The emergence of biotransformation technique to produce new natural drug as an antimicrobial agent was successfully reported. According to Muller ${ }^{19}$, fungi are effective in increasing the chemical diversity by producing new derivatives with lower toxicity but improved biological activity. While Kim et $\mathrm{al}^{20}$, described that the biotransformation afforded another metabolite that has higher antimicrobial activity compared to the parent metabolite. Thus, this approach successfully enhances the antimicrobial activity of the compound. For example, rhapontigenin produced from rhapontin by biotransformation showed 4-16 times higher antimicrobial activity than rhapontin. The activity was higher against Gram-positive strains than Gram-negative strains ${ }^{20}$. Another study by Srivastava et $\mathrm{al}^{21}$, indicates that $A$. flavus can transform artemisinin to deoxyartemisinin (Figure 1) and shows antibacterial activity against $S$. aureus, $S$. epidermidis and $S$. mutans at minimum inhibitory concentration (MIC) of $1 \mathrm{mg} / \mathrm{mL}$ compared to artemisinin whose MIC was $>2 \mathrm{mg} / \mathrm{mL}$. Siddhardha et al. ${ }^{22}$ showed biotransformation of (-)- $\alpha$-santonin using $A$. parasiticus resulted in the production of 3,4-epoxy- $\alpha$-santonin, 4,5-dihydro- $\alpha$-santonin and 1,2-dihydro- $\alpha$-santonin and evaluated for the biological activity of the transformed products. 3,4-epoxy- $\alpha$-santonin exhibited higher degree of antibacterial and antifungal activity. 4,5-dihydro- $\alpha$ santonin showed slight increase in the activity, compared to (-)- $\alpha$-santonin. 1,2-dihydro- $\alpha$ - santonin is equipotent to the substrate (-)- $\alpha$-santonin. This is the first report on the biotransformation of (-)- $\alpha$-santonin by $A$. parasiticus and evaluation of the biological activities of the biotransformed products.

Therefore, this present study was initiated to screen the antimicrobial activity of ethyl $p$ methoxycinnamate (EPMC), extracted from $K$. galanga Linn., and compare the bioactivity with its biotransformation metabolite, ethyl $p$ - hydroxycinnamate (EPHC) produced by $A$. niger.

\section{EXPERIMENTAL}

\section{Materials}

The rhizomes of $K$. galanga $L$. were collected at different locations throughout Malaysia in December 2013 and stored at $-20{ }^{\circ} \mathrm{C}$ prior to analysis. Five reference strains of human pathogens used for antimicrobial assay were Staphylococcus aureus (ATCC25923), Bacillus cereus (ATCC11778), Pseudomonas aeruginosa (ATCC27853) and Escherichia coli (ATCC8739) while one fungal strains was Candida albicans (IMRC533/11 A). The bacteria were maintained on Muller-Hinton Agar (MHA) and Muller- Hinton Broth (MHB) and stored in the refrigerator at $4^{\circ} \mathrm{C}$.Meanwhile, C. albicans was maintained on Sabouraud's Dextrose Agar (SDA) and stored in the refrigerator at $4^{\circ} \mathrm{C}$. Both bacteria and fungus $\mathrm{C}$. albicans were subcultured onto fresh media at regular interval.

\section{Extraction of $K$. galanga oil and purification of ethyl p-methoxycinnamate}

The fresh rhizomes of $K$. galanga were washed and cut into smaller pieces. The rhizomes were then extracted using steam distillation and supercritical fluid extraction (SFE) according to the previously reported method ${ }^{23}$. The essential oil was collected and stored at $-4^{\circ} \mathrm{C}$ for future analyses. For purification of ethyl p-methoxycinnamate (EPMC, 1) the essential oils were stirred with boiling water and then recrystalized at cold temperature $\left(-4^{\circ} \mathrm{C}\right)$. After crystallization, the mixture was filtered through Whatman No 1 and then the crystal was kept in the desiccator for 24 hours prior to further analysis.

\section{Fungus culture preparation and biotransformation procedure. \\ Aspergillus niger fungal culture preparation} Pure fungal culture of $A$. niger was obtained from Microbiology Laboratory Kulliyyah of Science, International Islamic University Malaysia. The pure fungus was streaked on Sabouraud Dextrose Agar slant (SDA) at $30{ }^{\circ} \mathrm{C}$ for a week and stored at 4 ${ }^{\circ} \mathrm{C}$. After cultivation, the well grown mycelia on the agar slants were placed in the conical flask $(250 \mathrm{ml})$ and inoculated with $10.0 \mathrm{ml}$ of sterilized medium broth containing glucose, glycerol, peptone, yeast extract, $\mathrm{KH}_{2} \mathrm{PO}_{4}, \mathrm{NaCl}$ and distilled $\mathrm{H}_{2} \mathrm{O}$. The flask 
was incubated using an incubator shaker for $48 \mathrm{hr}$ at $120 \mathrm{rpm}$ and $30^{\circ} \mathrm{C}$. Then, mycelia suspensions were transferred into 17 flasks containing sterile broth medium (100 $\mathrm{ml}$ of each) and incubated for 24 hour using the similar condition as reported earlier ${ }^{24}$.

\section{Biotransformation of the bioactive compounds}

Ethyl p-methoxycinnamate, $1(480 \mathrm{mg}$, ) was dissolved in dimethyl sulfoxide (DMSO) (24 $\mathrm{ml}$ ) and distributed among 48 flasks containing 24 hour stage culture (10 mg/0.5 ml in each flask) and continuously shaken for $24 \mathrm{~h}$ using a rotary shaker (120 rpm) at $30^{\circ} \mathrm{C}$. At the same time, a control flask having substrate without fungus and a control flask containing fungus without substrate were analysed in order to check the substrate ability and to determine the endogenous metabolite, respectively.

\section{Separation and purification of biotransformed product}

After incubation, the culture media and mycelium were separated using cotton in a funnel. Then, mycelium was washed with ethyl acetate (1.5 liter) while the culture media were extracted 3 times with ethyl acetate (2 liter). The combined organic extract was dried with anhydrous sodium sulphate $\left(\mathrm{Na}_{2} \mathrm{SO}_{4}\right)$ and evaporated using a rotary evaporator. The similar procedures were employed for the control group. The residues from both experimental and control group were analysed by TLC to confirm the presence of biotransformed product. The biotransformed products were isolated by column chromatography using silica gel column (200-300 mesh, Merck Ltd.) with hexane: ethyl acetate as solvent.

\section{Structural elucidation of the biotransformed product} Gas Chromatography/Mass Spectrometry (GC/ MS)

The crystal was further analyzed using an Agilent 5975C GC-MSD system (Agilent, Avondale, USA) equipped with a $30 \mathrm{~m} \times 0.25 \mathrm{~mm}$ i.d. $\times 0.25$ ìm , HP-5 capillary column (SGE, Australia) and $70 \mathrm{eV}$ of the electron impact technique. The carrier gas was helium at a flow rate of $1.3 \mathrm{~mL} / \mathrm{min}$. The crystal was dissolved in dichloromethane (DCM) at concentration of $1 \%$. Then, 1 ì of sample was injected into the column. The injector and detector temperatures were $250{ }^{\circ} \mathrm{C}$ and $230{ }^{\circ} \mathrm{C}$, respectively. The other analytical conditions were as follows: Temperature programming: $60^{\circ} \mathrm{C}$, as initial temperature, for $5 \mathrm{~min}, 8^{\circ} \mathrm{C} / \mathrm{min}$ to $180^{\circ} \mathrm{C}$ at $10^{\circ} \mathrm{C} /$ min to $240^{\circ} \mathrm{C}$, holding for $5 \mathrm{~min}$. Mass spectroscopy analysis was carried out using positive electron ionization method in order to obtain fragments of the compounds. The identification of compounds were based on a comparison of their retention times with those of authentic standards and by comparison of their mass spectra with those of data in the Wiley Registry of Mass Spectral Data and National Institute of Standards and Technology (NIST) libraries ${ }^{18}$. Low resolution mass spectrometry $(\mathrm{m} / \mathrm{z})$ was carried out on a VG Biotech Quattro II triple quadrupole instrument.

\section{Nuclear Magnetic Resonance (NMR) analysis}

The nuclear magnetic resonance (NMR) spectroscopy was used to elucidate the structure of compound ( 1 \& 2) using $1 \mathrm{D}\left(1 \mathrm{H}-\right.$ and $\left.{ }^{13} \mathrm{C}-\mathrm{NMR}\right)$ and $2 \mathrm{D}$ (COSY $45^{\circ}, \mathrm{HSQC}, \mathrm{HMBC}$ and NOESY) experiments according to the standard protocols. The NMR analysis was carried out at the Department of Chemistry, Universiti Kebangsaan Malaysia. ${ }^{1} \mathrm{H}$ and ${ }^{13} \mathrm{C}$ NMR spectra were recorded on a Bruker $400 \mathrm{MHz}$ FT-NMR spectrometer. The crystal was dissolved in $\mathrm{CD}_{2} \mathrm{Cl}_{2}$ and chemical shifts $(\alpha)$ are reported in ppm downfield of tetramethylsilane. Coupling constants $(\mathcal{J})$ are quoted in $\mathrm{Hz}$.

\section{Antimicrobial Assays Minimum Inhibitory Concentration (MIC)}

The test was performed using 96-well plates and prepared in a three-fold dilutions manner, where the concentration in each well is three times less than the preceding well. The first well for each sample (single compounds) was prepared in a 1000 $\mu \mathrm{g} / \mathrm{mL}$ concentration by mixing $30 \mu \mathrm{L}$ of the single compounds ( $10 \mathrm{mg} / \mathrm{mL}$ concentration) with $270 \mu \mathrm{L}$ broth media. After mixing the samples with the broth, the mixture $(100 \mu \mathrm{L})$ was transferred to the next well, in the same column, containing $200 \mu \mathrm{L}$ broth media. The similar procedure was repeated for the subsequent well until the end of each column. The final concentrations formed in each well after this process were 1000 (first well), 333, 111, 37, 12.3, 4.1, 1.37 , and $0.45 \mu \mathrm{g} / \mathrm{mL}^{25}$. 
Minimum Bactericidal/Fungicidal Concentration (MBC)

The minimum bactericidal/fingicidal concentration (MBC/MFC) test was carried out according to Betts et $\mathrm{al}^{26}$, with slight modifications in order to determine whether the MIC values only inhibit the growth or even kill the microorganism. $100 \mu \mathrm{L}$ of each broth in the well that represents MIC values for all bacteria and fungus was spread in MHA and SDA, respectively. Plates were kept in incubator for $24 \mathrm{hr}$. The MBC/MFC could be determined when the microorganisms were killed and unable to regrow back.

\section{RESULTS AND DISCUSSION}

Microbial transformation of ethyl p-methoxycinnamate (1) by $A$. niger afforded a main compound, identified as ethyl p-hydroxycinnamate (2) (Figure 2) in good yield (24\%). The molecular formula of 2 proved to be $\mathrm{C} 11 \mathrm{H} 12 \mathrm{O} 3$ from ${ }^{1} \mathrm{H}-\mathrm{NMR}$ and ${ }^{13} \mathrm{C}-\mathrm{NMR}$ data. The NMR spectral data of compound $\mathbf{2}$ are summarized in the Table 1. These finding presented a clear correlation to support the proposed structure and identified by comparing their spectra with literature ${ }^{27}$.

The antimicrobial assay in terms of the minimum inhibitory concentrations (MIC) of of ethyl $p$ - methoxycinnamate (EPMC) and ethyl $p$-hydroxycinnmate (EPHC) against different pathogenic bacteria and fungus are shown in Table 2.

MIC tests were done selectively against four types of bacteria which were $B$. cereus, $S$. aureus, $E$. coli, $P$. aeruginosa and one fungus which was $C$. albicans. The result showed that both compounds have good antimicrobial activities against all tested bacteria and fungus. The MIC values also indicated that both compounds (EPMC \& EPHC) were able to inhibit Gram-negative bacteria at lower

Table 1: ${ }^{1} \mathrm{H}-\mathrm{NMR},{ }^{13} \mathrm{C}-\mathrm{NMR}, \mathrm{COSY}$ and HMBC Spectral Data of EPHC, 2

\begin{tabular}{lllll}
\hline Position & ${ }^{13}$ C-NMR & 1H- NMR & COSY & HMBC \\
\hline 1 & $127.07, \mathrm{C}$ & - & - & \\
2,6 & $129.94, \mathrm{CH}$ & $7.4\left(2 \mathrm{H}, \mathrm{d}, J_{5}=J_{9}=8.4 \mathrm{~Hz}\right)$ & $\mathrm{H} 3,5$ & $\mathrm{C} 1,4,7$ \\
3,5 & $115.80, \mathrm{CH}$ & $6.8\left(2 \mathrm{H}, \mathrm{d}, J_{6}=J_{8}=9.0 \mathrm{~Hz}\right)$ & $\mathrm{H} 2,6$ & $\mathrm{C} 3,4,5$ \\
4 & $157.98, \mathrm{C}$ & - & - & \\
7 & $144.18, \mathrm{CH}$ & $7.6(1 \mathrm{H}, \mathrm{d}, J=15.6 \mathrm{~Hz})$ & $\mathrm{H} 8$ & $\mathrm{C} 1,8,9$ \\
8 & $115.55, \mathrm{CH}$ & $6.3(1 \mathrm{H}, \mathrm{d}, J=16.2 \mathrm{~Hz})$ & $\mathrm{H} 7$ & $\mathrm{C} 1,7,9$ \\
9 & $167.42, \mathrm{C}$ & - & - & \\
10 & $60.46, \mathrm{CH}$ & $4.2(2 \mathrm{H}, \mathrm{q}, J=7.2 \mathrm{~Hz})$ & $\mathrm{H} 11$ & $\mathrm{C} 11,9$ \\
11 & $14.12, \mathrm{CH}_{3}$ & $1.3(3 \mathrm{H}, \mathrm{t}, J=7.2 \mathrm{~Hz})$ & $\mathrm{H} 10$ & $\mathrm{C} 10$ \\
\hline
\end{tabular}

Table 2. Minimum Inhibitory Concentration (MIC) of ethyl p-methoxycinnamate (EPMC) and ethyl p-hydroxycinnamate (EPHC)

\begin{tabular}{lcc}
\hline Microorganisms & $\begin{array}{c}\text { Minimum Inhibitory Concentration } \\
(\mathbf{M I C}) \text { value }(\boldsymbol{\mu g} / \mathbf{m L})\end{array}$ \\
& EPMC, 1 & EPHC, 2 \\
\hline Staphylococcus aureus & 1000 & 333 \\
Bacillus cereus & 1000 & 333 \\
Escherichia coli & 333 & 111 \\
Pseudomonas aeruginosa & 333 & 111 \\
Candida albicans & 333 & 111 \\
\hline
\end{tabular}


Table 3. Minimum Bactericidal/Fungicidal Concentration (MBC/MFC) of ethyl p-methoxycinnamate (EPMC) and ethyl p-hydroxycinnamate (EPHC)

\section{Microorganisms}

MBF/MFC value $(\mu \mathrm{g} / \mathrm{mL})$

EPMC, 1 EPHC, 2

\begin{tabular}{llc}
\hline Staphylococcus aureus & - & 1000 \\
Bacillus cereus & - & 1000 \\
Escherichia coli & - & 1000 \\
Pseudomonas aeruginosa & - & 1000 \\
Candida albicans & - & 333 \\
\hline
\end{tabular}

concentrations compared to Gram-positive bacteria. The MIC value of ethyl $p$-hydroxycinnamate (EPHC) against both $E$. coli and $P$. aeruginosa was 111 $\mu \mathrm{g} / \mathrm{mL}$, which were more active than the value exhibited by ethyl $p$-methoxycinnamate (EPMC, $\mathrm{MIC}=333 \mu \mathrm{g} / \mathrm{mL}$ ) (Table 2). Meanwhile, the MIC values of EPHC against both $B$. cereus and $S$. aureus was $333 \mu \mathrm{g} / \mathrm{mL}$, which were also lower than the value exhibited by EPMC $(\mathrm{MIC}=1000 \mu \mathrm{g} / \mathrm{mL})$. Furthermore, EPHC was able to inhibit the growth of $\mathrm{C}$. albicans with the concentration that exhibited inhibition potential (MIC) was $111 \mu \mathrm{g} / \mathrm{mL}$ which were lower than the value exhibited by EPMC (MIC= $333 \mu \mathrm{g} / \mathrm{mL})$.<smiles>C[C@H]1CC[C@H]2[C@@H](C)C(=O)O[C@@H]3O[C@@]4(C)CC[C@@H]1[C@]32OO4</smiles>

Artemisinin

$(\mathrm{MIC}>2 \mathrm{mg} / \mathrm{mL})$

\section{Aspergillus flavus}

Deoxyartemisinin

(MIC: $1 \mathrm{mg} / \mathrm{mL}$ )

Fig. 1: Biotransformation of artemisinin to deoxyartemisinin by Aspergillus flavus

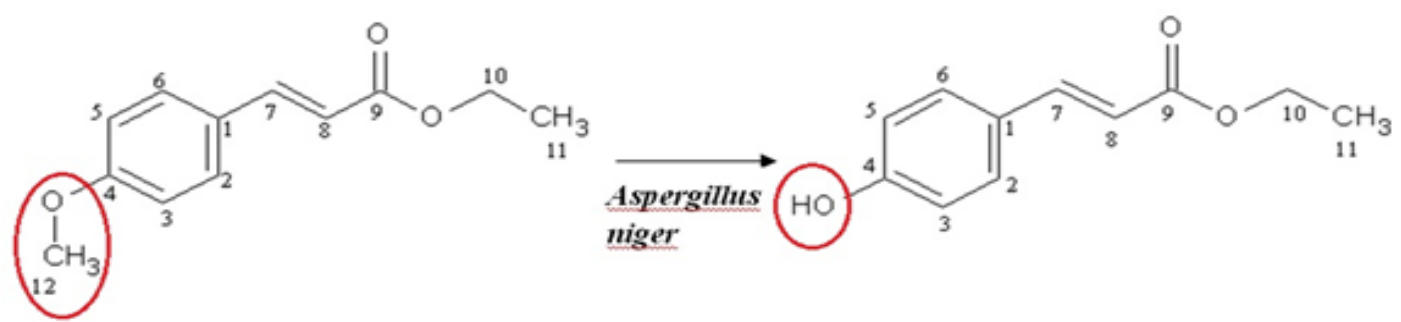

Fig. 2: Biotransformation pathway of ethyl p-methoxycinnamate into ethyl $p$-hydroxycinnamate acid by Aspergillus niger

In terms of minimum bactericidal concentration (MBC), there were bactericidal effect of EPHC against $S$. aureus, B. cereus, E. coli and $P$. aeruginosa at $1000 \mu \mathrm{g} / \mathrm{mL}$ and fungicidal effect (MFC) against Candida albicans at $333 \mu \mathrm{g} /$
$\mathrm{mL}$ (Table 3). However, there were no MBC was obtained for ethyl $p$-methoxycinnamate (EPMC) against all tested microorganisms. Hence, ethyl p-hydroxycinnamate (EPHC) has great potential to inhibit and killing the growth of Gram-positive 
bacteria, Gram-negative bacteria and fungus compared to ethyl $p$-methoxycinnamate (EPMC). The present of hydroxyl group in structure may increase the antimicrobial activities of compound ${ }^{28}$. The result has proved that the folkloric use of this plant in treating microbial infections and suggested that ethyl $p$-hydroxycinnamate (EPHC) could be exploited in future as one of the new antibiotics in line with the current drug development.

\section{CONCLUSION}

Biotransformation has been successfully utilized as a tool to generate pharmaceutical compounds from natural products. Through this process, ethyl $p$-methoxycinnamate (EPMC), extracted from Kaempferia galanga plant, was transformed using Aspergilus niger to ethyl p-hydroxycinnamate (EPHC), which shown antimicrobial activities.

Looking at the antimicrobial activities, ethyl $p$-hydroxycinnamate (EPHC) has an inhibitory potential effect against $S$. aureus, B. cereus, $P$. aeruginosa, E. coli and $C$. albican better than the effect by ethyl $p$-methoxycinnamate (EPMC). EPHC has also shown bactericidal and fungicidal effects against all tested bacteria and fungus while EPMC did not show killing potential toward them.

\section{ACKNOWLEDGEMENTS}

The authors would like to express greatest appreciation and gratitude to the International Islamic University of Malaysia (IIUM) and The Ministry of Higher Education (MOHE) for financial support (RMGS). Also thank to all Kulliyyah of Science (KOS) and IIUM staff for technical supports.

\section{REFERENCES}

1. Navneet, P.; Krishna, S. Environ. Conserv. J. 2005, 3, 59-61

2. Sule A.; Ahmed Q. U.; Latip J.; Samah O. A.; Omar, M. N.; Umar, A.; Dogarai, B. B. S., Pharmaceutical Biology 2012, 50, 850-856

3. Sule, A.; Ahmed, Q. U.; Hassan, N. M.; Kama.I L. Z. M.; Samah O. A.; Omar M. N.; Yarmo, M. A. American Journal of Applied Sciences 2012, 8, 525-534

4. Sule, A.; Ahmed, Q. U.; Samah, O. A.; Omar, M. N. Journal of Medicinal Plant Research 2012, 5, 7-14

5. Sule, A.; Ahmed, Q.U.; Samah, O. A.; Omar, M. N. Ethnobotanical Leaflets 2010, 14, 445456

6. Mahmood, A.; Omar, M. N.; Ngah, N. Asian Pacific Journal of Tropical Medicine 2012, 5, 882-886

7. Nor, M. M.; Hassan, H. H. M.; Nik Mohamad Ravi, N. H. N. R.; Omar, M. N. J. Agric. Sci. Technol. B 2014, 4, 195-199

8. Omar, M. N. J. Trop. Agric. Food Sci. 1999, 27, 225-229

9. Omar, M. N. J. Trop. Agric. Food Sci. 1999, 27, 231-236

10. Omar, M. N.; Kasbon, S. N. Teknologi Pertanian 1981, 4, 185-188
11. Tara, K.; Muzammil, A.; Abdullateef, R. A.; Omar, M. N. Journal of Medicinal Plant Research 2012, 6, 4354-4357

12. De Pooter, H. L.; Omar, M. N.; Coolsaet, B. A.; Schamp, N. A. Phytochemistry 1985, 24, 93-96

13. Alfarra, H. Y.; Omar, M. N. International Journal of Pharma Medicine and Biological Sciences, 2014, 3, 1-8

14. Kanjanapothi, D.; Panthong, A.; Lertprasertsuke, N.; Taesotikul, T.; Rujjanawate, C.; Kaewpinit, D.; Sudthayakom, R.; Choochote, W.; Chaithong, U.; Jitpakdi, A.; Pitasawat, B. J. Ethnopharmacol. 2004, 90: 359-365

15. Kochuthressia, K. P.; Britto, S.J.; Jaseentha, M.; Raphael, R. Am. J. Biotechnol. Mol. Sci. 2012, 2, 1-5.

16. Othman, R.; Ibrahim, H.; Mohd, M. A.; Awang, K.; Gilani, A. V.; Musthafa, M. R. Planta Med. 2002, 68, 655-657.

17. Vimala, S.; Norhanom A.W.; Yadav, M. Br. J. Cancer, 1999, 80, 110-116

18. Liu B., Liu F., Chen C., and Gao H. Nat. Prod. Res. 2010, 24, 1927-1932

19. Muller, M. Cur. Opin. Biotechnol. 2004, 15, 591-598 
20. Kim, J. K.; Kim, N.; Lim, Y. H. J. Microbiol, Biotechnol. 2010, 20, 82-87

21. Srivastava , S.; , Luqman , S.; Fatima , A.; Darokar, M.; Negi , A.; , Kumar , J.; Shanker , K.; Chanotiya, C.; Tandon , S.; Khanuja , S. Sci Pharm. 2009; 77, 87-95

22. Siddhardha B.; Gadupudi, R.; Rao, M. V. B. Cur. Biotechnol. 2012, 1, 194-198

23. Omar, M. N.; Razman, S.; Nor-Nazuha, M. N.; Nazreen, M.; Ahmad Muzammil Zuberdi, A. M. Oriental J. Chem. 29, 89-92

24. Choudhary, M. I.; Musharraf, S. G.; Sami, A.; Atta-ur-Rahman. Helv. Chim. Acta 2004, 87, 2685-2694

25. Qaralleh, H.; Idid, S.; Saad, S.; Susanti, D.;
Taher, M.; Khleifat, K. J. Med. Mycol. 2010, 20, 315-320

26. Betts, J.; Murphy, C.; Kelly, S.; Haswell, S. Journal of Microbiology, Biotechnology and Food Sciences, 2012, 1,1250-1258

27. Barbosa-Filho, J. M.; Lima, C. S. A.; Amorim, E. L. C.; De Sena, K. X. F. R.; Almeida, J. R. G. S.; Emidio Vasconcelos L Da-Cunha, E. V. L.; Silva, M. S.; Maria de Fatima Agra, M., Braz-Filho, R. International Journal of Botanica Experimental. 2004, 221-228

28. Gouiric, S. C.; Feresin, G. E.; Tapia, A. A.; Rossomando, P.C.; Schmeda-Hirschmann, G.; Bustos, D. A. World J. Microbiol. Biotechnol. 2004, 20, 281-284. 